\title{
Meningkatkan Hasil Belajar IPA Melalui Metode Eksperimen Pada Siswa Kelas IV SDN 02 Kota Mukomuko
}

\author{
Ratna Juita ${ }^{1}$ \\ ${ }^{1}$ State Elementary School 02 City of Mukomuko, Indonesia \\ Coressponding Author. E-mail: \\ ${ }^{1}$ ratnajuitaa71@gmail.com \\ Received: 10 November 2018 \\ Accepted: 25 Desember 2018 \\ Online Published: 13 Januari 2019
}

\begin{abstract}
Abstrak
Pembelajaran yang terjadi sebelum penelitian ini dilakukan, terdapat penyampaian materi tidak efisien dan kurang mempunyai daya tarik, bahkan cenderung membosankan, sehingga hasil belajar yang dicapai tidak optimal pada siswa kelas IV di SD Negeri 02 Kota Mukomuko. Dari duapuluh siswa, hanya sembilan orang $(45 \%)$ siswa yang telah tuntas, sementara sebelas orang $(55 \%)$ lainnya masih di bawah kriteria ketuntasan mengajar (KKM). Oleh karena hal tersebut, maka perlu diterapkan pembelajaran untuk perbaikan melalui PTK. Penelitian ini menggunakan dua siklus yang setiap siklusnya terdiri dari empat tahapan. Penelitian tindakan kelas ini bertujuan untuk meningkatkan hasil belajar IPA melalui metode eksperimen. Hasil penelitian menunjukkan terdapat kemajuan yang signifikan. Pada akhir siklus terdapat 18 (90\%) siswa yang telah memenuhi KKM.
\end{abstract}

Kata Kunci: Penelitian Tindakan Kelas, Hasil Belajar IPA, Eksperimen Sekolah

\section{Improving Science Learning Outcom Through Experiment Method on $4^{\text {th }}$ Grade State Elementary School 02 (SDN 02) Students, City Of Mukomuko}

\begin{abstract}
Learning that occurred before this research was conducted, there was inefficient delivery of material and lacked attractiveness, and even tended to be boring, so that the learning outcomes achieved were not optimal for grade IV students at SD Negeri 02 Kota Mukomuko. Of the twenty students, only nine people (45\%) were completed, while eleven people (55\%) were still below the teaching completeness criteria (KKM). Because of this, learning needs to be improved for PTK. This study uses two cycles, each of which consists of four stages. This classroom action research aims to improve science learning outcomes through experimental methods. The results of the study showed significant progress. At the end of the cycle there were 18 (90\%) students who had met the KKM.
\end{abstract}

Keywords: Classroom Action Research, Science Learning Outcome, School Experiment. 


\section{PENDAHULUAN}

Guru adalah orang yang paling berperan dalam menciptakan sumber daya manusia yang berkualitas yang dapat bersaing di zaman pesatnya perkembangan teknologi. Guru SD Negeri 02 Kota Mukomuko dalam setiap pembelajaran selalu menggunakan pendekatan, strategi dan metode pembelajaran yang dapat memudahkan siswa memahami materi yang diajarkannya, namun masih sering terdengar keluhan dari para guru di lapangan tentang materi pelajaran yang terlalu banyak dan keluhan kekurangan waktu untuk mengajarkannya semua

Berdasarkan hasil pengamatan penulis, dalam pelaksanaan pembelajaran di kelas penggunaan model pembelajaran yang bervariatif masih sangat rendah dan guru cenderung menggunakan model pembelajaran konvesional pada setiap pembelajaran yang dilakukannya. Hal ini mungkin disebabkan kurangnya penguasaan guru terhadap model-model pembelajaran yang ada, padahal penguasaan terhadap model-model pembelajaran sangat diperlukan untuk meningkatkan kemampuan profesional guru, dan sangat sesuai dengan kurikulum.

Untuk itu guru perlu meningkatkan mutu pembelajarannya, dimulai dengan rancangan pembelajaran yang baik dengan memperhatikan tujuan, karakteristik siswa, materi yang diajarkan, dan sumber belajar yang tersedia. Kenyataannya masih banyak ditemui proses pembelajaran yang kurang berkualitas, tidak efisien dan kurang mempunyai daya tarik, bahkan cenderung membosankan, sehingga hasil belajar yang dicapai tidak optimal. Hal ini dapat dilihat dari hasil belajar IPA siswa kelas IV di SD Negeri 02 Kota Mukomuko .

Dari 20 siswa 9 orang (45\%) siswa yang telah tuntas, sementara 11 orang $(55 \%)$ lainnya masih di bawah KKM. Oleh karena hal tersebut, maka perlu diterapkan pembelajaran yang dapat meningkatkan hasil belajar siswa. Pembelajaran yang perlu dilaksanakan adalah pembelajaran yang melibatkan siswa dalam proses belajar. Salah satu metode yang melibatkan siswa dalam proses belajar adalah metode eksperimen.

Masalah-masalah di lapangan yang dapat diidentifikasi adalah ; 1) Rendahnya perolehan hasil belajar mata pelajaran IPA siswa kelas IV SD Negeri 02 Kota Mukomuko menunjukkan adanya indikasi terhadap rendahnya aktivitas belajar siswa dan kemampuan guru dalam mengelola pembelajaran yang berkualitas, 2) Metode pembelajaran yang digunakan siwa dalam pembelajaran belum bervariasi dan menggunakan model pembelajaran konvensional pada setiap pembelajaran yang dilakukannya, dan 3) Guru belum menggunakan media maupun metode pembelajaran yang sesuai dengan konteks pembelajaran di kelas. 4) Guru menyampaikan materi pelajaran kurang menarik menurut para siswa.

Sebelum membahas solusi dari permasalahan yang timbul di lapangan perlu dibahas terlebih dahulu kajian pustaka yang mendukung penelitian tersebut. Diantaranya adalah kajian tentang IPA, kajian pembelajaran IPA di SD, kajian metode eksperimen di sekolah, dan kajian hasil belajar.

\section{Kajian IPA}

Kajian yang pertama adalah IPA. Pembelajaran IPA atau Ilmu Pengetahuan Alam di Sekolah Dasar merupakan penguasaan siswa terhadap pengetahuan tentang alam sekitar, yang dipelajari dari fakta-fakta, prinsip-prinsip dan proses penemuan. Pengetahuan siswa tentang alam tersebut dapat mencetak siswa dalam bersikap ilmiah. Namun Materi IPA yang diberikan harus disesuaikan dengan usia dan karakteristik siswa yang bersangkutan. Maksudnya, materi IPA yang diberikan kepada siswa disesuaikan dengan tingkat kelas, sehingga penguasaan pengetahuan tentang IPA dapat bermanfaat baik bagi dirinya (siswa) maupun bagi kelestarian lingkungan Alam Sekitar. Pengertian IPA (Ilmu Pengetahuan Alam) Menurut H.W. Fowler et-al adalah ilmu yang sistematis dan dirumuskan, dimana berhubungan dengan gejalagejala kebendaan dan didasarkan terutama atas pengamatan dan induksi.

Pendidikan IPA diharapkan dapat menjadi wahana bagi peserta didik untuk mempelajari diri sendiri dan alam sekitar, serta prospek pengembangan lebih lanjut dalam penerapannya di dalam kehidupan sehari-hari. Proses pembelajarannya menekankan pada pemberian pengalaman langsung untuk mengembangkan kompetensi agar menjelajahi dan memahami alam sekitar secara ilmiah. Pendidikan IPA diarahkan untuk inkuiri dan berbuat sehingga dapat membantu peserta didik untuk memperoleh pemahaman lebih mendalam tentang alam sekitar. BNSP (2007:13).

Ilmu Pengetahuan Alam (IPA) sebagai disiplin ilmu dan penerapannya dalam masyarakat membuat pendidikan IPA menjadi penting. Tentu saja Materi pembelajarannya harus disesuaikan dengan kondisi dan karateristik siswa dalam hal ini sebagai penerima informasi. Hal ini dilakukan agar pembelajaran yang diterima dapat bermanfaat bagi siswa dalam kehidupannya. 
Adapun IPA dalam Pendidikan Dasar dalam Usman Samatowa (2006: 12) didefinisikan oleh Paolo dan Marten yaitu mengamati apa yang terjadi, mencoba apa yang diamati, mempergunakan pengetahuan baru untuk meramalkan apa yang akan terjadi dan menguji bahwa ramalan-ramalan itu benar.

\section{Kajian Eksperimen}

Metode Eksperimen adalah Suatu cara mengajar, dimana siswa melakukan suatu percobaan tentang sesuatu hal ,mengamati prosesnya serta menuliskan hasil percobaannya, kemudian hasil pengamatan itu disampaikan ke kelas dan dievaluasi oleh guru.

Penggunaan teknik ini mempunyai tujuan agar siswa mampu mencari dan menemukan sendiri berbagai jawaban atau persoalan-persoalan yang dihadapinya dengan mengadakan percobaan sendiri. Juga siswa dapat terlatih dalam cara berpikir yang alamiah. Dengan eksperiman siswa menemukan bukti kebenaran dari teori sesuatu yang dipelajari.

Agar penggunaan metode eksperimen itu efisien dan efektif, maka perlu diperhatikan hal-hal sebagai berikut :

a. Setiap siswa harus mengadakan percobaan, maka jumlah alat dan bahan atau materi percobaan harus cukup bagi setiap siswa.

b. Agar eksperimen itu tidak gagal dan siswa menemukan bukti yang meyakinkan, atau mungkin hasilnya tidak membayakan, maka kondisi alat dan mutu bahan percobaan yang digunakan harus baik dan bersih.

c. Perlu teliti dan konsentrasi dalam mengamati proses percobaan, maka perlu adanya waktu yang cukup lama, sehingga mereka menemukan pembuktian kebenaran dari teori yang dipelajari itu.

d. Dalam melaksanakan eksperimen berarti sedang belajar dan berlatih, maka perlu diberi petunjuk yang jelas, sebab perlu diberikan petunjuk yang jelas, sebab mereka disamping memperoleh pengetahuan, pengamatan serta keterampilan, juga kematangan jiwa dan sikap perlu diperhitungkan oleh guru dalam memilih objek eksperimen itu.

e. Tidak semua masalah bisa dieksperimen, seperti masalah menyenai kejiwaan, beberapa segi kehidupan sosial dan keyakianan manusia. Kemungkinan lain karna sangat terbatasnaya suatu alat, sehingga masalah itu tidak bisa diadakan percobaan kerena alatnya belum ada.
Kelebihan metode eksperimen dalam mengajar ini adalah ; 1) Membuat siswa lebih percaya atas kebenaran atau kesimpulan berdasarkan percobaannya. 2) Dalam membina siswa untuk membuat terobosan-terobosan baru dengan penemuan dari hasil percobaannya dan manfaat bagi kehidupan manusia. 3) Hasil-hasil percobaan yang berharga dapat dimanfaatkan untuk kemakmuran umat manusia.

Oleh karena itu perlu sebuah metode yang menjadi solusi dan sesuai untuk mengatasi masalah tersebut. Penulis mencoba menggunakan metode eksperimen dalam usaha untuk meningkatkan hasil belajar siswa pada mata pelajaran IPA.

\section{METODE}

Kajian ini menggunakan studi literatur untuk mengungkapkan teori, konsep, penelitian terdahulu, dan pendapat para ahli sebagai landasan untuk menjelaskan optimalisasi model pembelajaran ARCS dan motivasi belajar peserta didik sebagai upaya meningkatkan motivasi belajar peserta didik dalam pembelajaran saintifik pada peminatan mata pelajaran geografi.

Metode penelitian yang digunakan yaitu metode penelitian tindakan kelas. Penelitian ini dilaksanakan dalam tiga siklus dengan mengunakan model PTK dari IGAK. Wardhani dan Kuswaya Wihardit (2009:2.4), dimana setiap siklusnya terdiri atas beberapa tahap yaitu (1) Perencanaan, (2) Pelaksanaan, (3) Pengamatan, dan (4) Refleksi. Secara lebih terperinci sebagai berikut.

\section{Siklus I}

Pada siklus I ini peneliti merencanakan dan merancang tindakan perbaikan sebagai tindak lanjut pembelajaran dari Pra siklus yang dianggap kurang berhasil. Siklus I ini dilaksanakan pada tanggal 25 April 2018 yang urutannya sebagai berikut:

\section{Tahap Perencanaan}

Pada tahap ini kegiatan yang akan dilakukan mencakup:

a. Menyusun Rencana Perbaikan Pembelajaran.

b. Membuat LKS.

c. Menyusun kisi-kisi soal.

d. Menyusun lembar observasi guru.

e. Menyusun lembar observasi siswa.

f. Mempersiapkan alat/media dan bahan yang akan dipergunakan pada waktu perbaikan pembelajaran.

g. Menyusun alat evaluasi berupa soal tes essay. 


\section{Tahap Pelaksanaan}

Tindakan dilaksanakan dengan berdasarkan pada skenario pembelajaran yang telah di buat. Langkah-langkah yang dilakukan untuk pelaksanaan siklus I adalah :

a. Kegiatan Awal

1. Guru membuka pelajaran dengan mengkondisikan kelas untuk belajar.

2. Guru mengabsensi kehadiran siswa.

3. mengadakan apersepsi dengan membangkitkan motivasi siswa dengan pertanyaan tentang gaya.

4. Guru menyampaiakan kepada siswa tentang tujuan pembelajaran dan materi pokok yang akan dipelajari.

b. Kegiatan Inti

1. Dengan metode eksperimen, guru bertanya jawab dengan siswa tentang bentuk gaya.

2. Siswa diminta membaca buku pelajaran IPA tentang Gaya

3. Tanya jawab tentang Gaya

c. Kegiatan Akhir

1. Guru bersama siswa menarik kesimpulan tentang materi yang sudah dipelajari.

2. Guru memberikan tugas berupa latihan.

3. Guru menutup pelajaran.

\section{Tahap Pengamatan}

Pada pelaksanaan Siklus I dilaksanakan pengamatan terhadap kegiatan pembelajaran yang sedang berlangsung dengan menggunakan lembar observasi yang di isi oleh pengamat atau supervisor 2. Pengamat memberikan tanda $(\sqrt{ })$ terhadap aspek yang diamati berdasarkan indikatornya. Pada akhir pelaksanaan Siklus I diadakan evaluasi yang berupa tes tertulis yang berbentuk essay.

\section{Tahap Refleksi}

Pada tahap ini dilakukan analisis terhadap hasil observasi dan evaluasi. Hasil dari analisis tersebut dijadikan sebagai acuan atau pedoman bagi peneliti untuk melaksanakan perbaikan pada Siklus II.

\section{Siklus II}

Pada siklus II inipeneliti merencanakan dan merancang tindakan perbaikan sebagai tindak lanjut pembelajaran dari Siklus I yang dianggap kurang berhasil. Siklus II ini dilaksanakan pada tanggal 03 Mei 2018 yang urutannya sebagai berikut:

\section{Tahap Perencanaan}

Pada tahap ini kegiatan yang akan dilakukan mencakup: a. Menyusun Rencana Perbaikan Pembelajaran.

b. Membuat LKS.

c. Menyusun kisi-kisi soal.

d. Menyusun lembar observasi guru.

e. Menyusun lembar observasi siswa.

f. Mempersiapkan alat/media dan bahan yang akan dipergunakan pada waktu perbaikan pembelajaran.

g. Menyusun alat evaluasi berupa soal tes essay.

2. Tahap pelaksanaan

Tindakan dilaksanakan dengan berdasarkan pada skenario pembelajaran yang telah di buat. Langkah-langkah yang dilakukan untuk pelaksanaan siklus II adalah:

\section{a. Kegiatan Awal}

1. Guru membuka pelajaran dengan mengkondisikan kelas untuk belajar.

2. Guru mengabsensi kehadiran siswa.

3. Guru mengadakan apersepsi dengan membangkitkan motivasi siswa dengan pertanyaan tentang sudut.

4. Guru menyampaiakan kepada siswa tentang tujuan pembelajaran dan materi pokok yang akan dipelajari.

\section{b. Kegiatan Inti}

1. Dengan metode eksperimen guru memberikan lembar kerja siswa berupa gambar macam gaya

2. Dengan tanya jawab, guru meminta siswa siswa untuk memahami macam Gaya dan pengaruhnya terhadap Gaya.

3. Tanya jawab tentang Gaya.

$$
\text { c. Kegiatan Akhir }
$$

1. Guru bersama siswa menarik kesimpulan tentang materi yang sudah dipelajari.

2. Guru memberikan tugas berupa latihan.

3. Guru menutup pelajaran.

\section{Tahap Pengamatan}

Pada pelaksanaan Siklus II dilaksanakan pengamatan terhadap kegiatan pembelajaran yang sedang berlangsung dengan menggunakan lembar observasi yang di isi oleh pengamat atau supervisor 2. Pengamat memberikan tanda $(\sqrt{ })$ terhadap aspek yang diamati berdasarkan indikatornya. Pada akhir pelaksanaan Siklus II diadakan evaluasi yang berupa tes tertulis yang berbentuk essay.

\section{Tahap Refleksi}

Pada tahap ini dilakukan analisis terhadap hasil observasi dan evaluasi. Hasil dari analisis tersebut dijadikan sebagai acuan atau pedoman bagi peneliti untuk melaksanakan perbaikan pada Siklus III.

\section{Siklus III}

Pada siklus III ini peneliti merencanakan dan merancang tindakan perbaikan sebagai tindak 
lanjut pembelajaran dari Siklus II yang dianggap kurang berhasil. Siklus III ini dilaksanakan pada tanggal 03 Mei 2018 yang urutannya sebagai berikut:

\section{Tahap perencanaan}

Pada tahap ini kegiatan yang akan dilakukan mencakup:

a. Menyusun Rencana Perbaikan Pembelajaran.

b. Membuat LKS.

c. Menyusun kisi-kisi soal.

d. Menyusun lembar observasi guru.

e. Menyusun lembar observasi siswa.

f. Mempersiapkan alat/media dan bahan yang akan dipergunakan pada waktu perbaikan pembelajaran.

g. Menyusun alat evaluasi berupa soal tes essay.

2. Tahap pelaksanaan

Tindakan dilaksanakan dengan berdasarkan pada skenario pembelajaran yang telah di buat. Langkah-langkah yang dilakukan untuk pelaksanaan siklus III adalah :

\section{a. Kegiatan Awal}

1. Guru membuka pelajaran dengan mengkondisikan kelas untuk belajar.

2. Guru mengabsensi kehadiran siswa.

3. Guru mengadakan apersepsi dengan membangkitkan motivasi siswa dengan pertanyaan tentang gaya.

a. Anak-anak, mencoba mendorong meja dan gaya apa yang dihasilkan?

b. Coba perhatikan katapel gaya apa yang dihasilkan oleh katapel tersebut?

4. Guru menyampaikan kepada siswa tentang materi pokok yang akan dipelajarai serta tujuan pembelajaran.

\section{b. Kegiatan Inti}

1. Guru bertanya jawab dengan siswa tentang macam - macam gaya.

2. Dengan metode eksperimen, guru melibatkan siswa melakukan percobaan menggunakan alat peraga yaitu : Bola, penghapus papan tulis, karet, magnet, botol kosong.

3. Guru membimbing siswa dalam pemecahan masalah tersebut.

4. Tanya jawab tentang Gaya.

c. Kegiatan Akhir

1. Guru bersama siswa menarik kesimpulan tentang materi yang sudah dipelajari.

2. Guru memberikan tugas berupa latihan.

3. Guru menutup pelajaran.

3. Tahap pengamatan

Pada pelaksanaan Siklus III dilaksanakan pengamatan terhadap kegiatan pembelajaran yang sedang berlangsung dengan menggunakan lembar observasi yang di isi oleh pengamat atau supervisor 2. Pengamat memberikan tanda $(\sqrt{ })$ terhadap aspek yang diamati berdasarkan indikatornya.

Pada akhir pelaksanaan Siklus III diadakan evaluasi yang berupa tes tertulis yang berbentuk essay.

\section{Tahap refleksi}

Pada tahap ini dilakukan analisis terhadap hasil observasi dan evaluasi. Hasil dari analisis tersebut dijadikan rekomendasi bagi penelitian ini untuk pembuatan laporan karena pada kegiatan siklus III ini hasil belajar siswa sudah berhasil.

Setelah tahapan-tahapan dalam kegiatan penelitian tindakan kelas tersebut dilakukan maka untuk menentukan data yang diambil peneliti menggunakan beberapa instrument pengambilan data, diantaranya adalah:

- Lembar Observasi

Lembar observasi ini dilakukan pada saat proses pembelajaran berlangsung yang di isi oleh pengamat dengan memberikan tanda $(\sqrt{ })$ terhadap aspek yang diamati berdasarkan indikatornya. Lembar observasi yang digunakan dalam penelitian ini yaitu:

a. Lembar observasi guru.

b. Lembar observasi siswa.

- LembarTes

Lembar tes yang digunakan dalam penelitian ini berbentuk tes tertulis yang dilaksanakan pada akhir proses pembelajaran untuk mengetahui seberapa jauh prestasi belajar yang telah dicapai oleh siswa.

Setelah data diambil dengan menggunakan instrument pengambilan data, maka langkah selanjutnya adalah menganalisis data yang telah diambil.

- Analisis Data Observasi.

Untuk menganalisis data observasi dilakukan secara deskriptif dengan menghitung skor dari pengamat. Data observasi yang diperoleh digunakan untuk merefleksi tindakan yang telah dilakukan dan diolah secara deskriptif dengan menghitung: 
Kisaran nilai untuk tiap kriteria $=$ selisih skor

jumlah kriteria penilaian

- Observasi aktivitas guru

Jumlah butir observasi 11 dengan skor tertinggi 33 dan skor terendah 11. Selisih skor adalah 33-11 $=22$, Kisaran nilai untuk tiap kriteria adalah $22 / 7=7,3$ (dibulatkan menjadi 7). Untuk mengetahui hasil kisaran tiap katagori pengamatan dapat dilihat pada tabel 1.

Tabel 1. Tabel kisaran nilai tiap katagori pengamatan guru

\begin{tabular}{cccl}
\hline \hline No & & Skor & Kriteria \\
\hline \hline 1 & & $11-$ & Kurang \\
2 & 18 & $19-$ & Cukup \\
& 26 & $27-$ & Baik \\
3 & 34 & & \\
\hline
\end{tabular}

- Observasi aktifitas siswa

Jumlah butir observasi 6 dengan skor tertinggi 11 dan skor terendah 5 . Selisih skor adalah 11-5 = 4, Kisaran nilai untuk tiap kariteria adalah $12 / 3=4$. Untuk mengetahui hasil kisaran tiap katagori pengamatan dapat dilihat pada tabel berikut.

Tabel 2. Tabel kisaran nilai tiap katagori pengamatan siswa

\begin{tabular}{lll}
\hline \hline No & Skor & Kriteria \\
\hline \hline 1 & $6-10$ & Kurang \\
2 & $11-15$ & Cukup \\
3 & $16-20$ & Baik \\
\hline
\end{tabular}

- Analisis Data Hasil Belajar

Data tes dianalisis dengan menggunakan rata-rata nilai dan persentase ketuntasan belajarpada tiap siklus dengan menggunakan rumus

1. Nilai rata-rata $=\frac{\sum x}{N}$

Keterangan : $\begin{aligned} \sum x & =\text { Jumlah nilai } \\ \mathrm{N} & =\text { Jumlah siswa }\end{aligned}$
2. Persentase ketuntasan belajar $=\frac{N S}{N} \times 100 \%$

Keterangan :

NS = Jumlah siswa yang mencapai nilai $\geq 7,0$

$\mathrm{N}=$ Jumlah seluruh siswa

\section{HASIL DAN PEMBAHASAN}

\section{HASIL}

\section{Prasiklus}

Pembelajaran prasiklus dilaksanakan pada Hari Senin tanggal 16 April 2018. Hasil tes siswa pada prasiklus ditampilkan pada tabel 3. dalam lampiran.

Hasil belajar prasiklus, jumlah siswa yang tuntas adalah 9 orang $(45 \%)$ dan siswa yang belum tuntas adalah 11 orang $(55 \%)$. Sementara rata-rata nilai siswa adalah 65,2. Ini terlihat bahwa jumlah siswa yang tuntas masih rendah dan jumlah siswa yang belum tuntas masih banyak serta rata-rata nilai siswa juga masih rendah.

\section{Siklus I}

Pembelajaran siklus I dilaksanakan pada Hari Rabu tanggal 25 April 2018. Hasil tes siswa pada siklus I ditampilkan pada tabel 4 dalam lampiran.

Hasil belajar siklus I, jumlah siswa yang tuntas adalah 13 orang atau $65 \%$ dan siswa yang belum tuntas adalah 7 orang $35 \%$. Sementara ratarata nilai siswa adalah 71,8 . Jumlah siswa yang tuntas pada siklus I meningkat dari prasiklus dan rata-rata nilai siswapun meningkat $20 \%$.

\section{Siklus II}

Pembelajaran siklus II dilaksanakan pada Hari kamis tanggal 3 Mei 2018. Hasil tes siswa pada siklus II ditampilkan pada tabel 5 dalam lampiran.

Hasil belajar siklus II, jumlah siswa yang tuntas telah mencapai 18 orang atau 90\% sementara siswa yang belum tuntas hanya 2 orang $10 \%$. Ini terjadi peningkatan siklus I. Rata-rata nilai siswa adalah 77,6 dan juga meningkat dari siklus I.

Berdasarkan hasil perbaikan pembelajaran yang telah dilakukan, terlihat adanya perubahan pada setiap siklus, prasiklus dengan perolehan nilai rata-rata 65,8 dan siklus I meningkat menjadi 71,8 dan meningakt lagi pada siklus II menjadi 77,6. Sementara itu jumlah siswa yang tuntas pada prasiklus adalah 9 orang atau $45 \%$, selanjutnya terjadi peningkatan pada siklus I menjadi 13 orang atau $65 \%$. Terakhir pada siklus II jumlah siswa yang tuntas telah mencapai $90 \%$. 


\section{PEMBAHASAN}

Pada prasiklus penelitian perbaikan pembelajaran yang dilakukan di kelas IV SD Negeri 02 Kota Mukomuko dengan menggunakan metode pembelajaran eksperimen pada mata pelajaran IPA, guru kurang mengoptimalkan pembelajaran sehingga sebagian siswa masih ditemukan kurang aktif dalam pembelajaran. Sementara pada siklus I, kekurangan tersebut diatasi dengan melakukan perbaikan pembelajaran dari prasiklus dengan pelaksanaan metode eksperimen secara maksimal. Pada prasiklus, masih ada siswa yang belum terlibat dalam pembelajaran, sehingga pada siklus I, guru mengusahakan siswa terlibat dengan mengotimalkan diskusi kelompok dan presentasi kelompok.

Selanjutnya, proses pembelajaran pada siklus I juga dievaluasi, sehingga pada siklus II hasil belajar siswa terus meningkat. Pada siklus II guru memotivasi siswa dengan lebih sering memberi pujian dan penguatan kepada siswa yang aktif. Guru juga memacu siswa untuk berkompetisi menjadi yang terbaik.

Berdasarkan hasil perbaikan pembelajaran yang telah dilakukan pada mata pelajaran IPA siswa kelas IV SD Negeri 02 Kota Mukomuko, maka sudah terlihat menunjukan kemajuan. Hal tersebut terlihat dari peningkatan hasil belajar siswa pada setiap pertemuan. Sehingga dapat disimpulkan telah berhasil meningkatkan hasil belajar IPA siswa kelas IV SD Negeri 02 Kota Mukomuko dengan menggunakan metode eksperimen.

\section{SIMPULAN (5\%)}

Dari keseluruhan hasil penelitian dengan menggunakan metode eksperimen dalam pembelajaran IPA pada siswa kelas IV SD Negeri 02 Kota Mukomuko, ternyata berpengaruh terhadap peningkatan hasil belajar siswa. Berdasarkan hasil perbaikan pembelajaran yang telah dilakukan, terlihat adanya peningkatan ratarata nilai hasil belajar siswa dari 65,8 pada prasiklus, meningkat menjadi 71,8 dan meningkat lagi menjadi 77,6 pada siklus II. Sementara itu jumlah siswa yang tuntas pada prasiklus $45 \%$, pada siklus I meningkat menjadi $65 \%$ meningkat lagi menjadi $90 \%$ pada siklus II.

Berdasarkan hasil penelitian yang telah dilakukan, maka disarankan hal-hal sebagai berikut ; 1) Dalam pelaksanaan program perbaikan pembelajaran guru hendaknya memfokuskan perhatian terhadap kelemahan-kelemahan pembelajaran sebelumnya. 2) Guru merupakan sosok yang selalu ditiru oleh siswa, selain guru juga merupakan ujung tombak peningkatan mutu pendidikan, sehingga guru perlu terus memacu dirinya untuk memperbaiki proses pembelajaran, mampu menciptakan suasana belajar yang kondusif, bersikap inovatif, 3) Guru harus selalu memberikan motivasi belajar, mengembangkan kreatifitas belajar, menarik minat dan perhatian siswa, 4) Kepala sekolah hendaknya selalu memberikan motivasi dan mensponsori untuk menerapkan metode dan media pembelajaran. 


\section{DAFTAR PUSTAKA}

Depdiknas. (2006). Kurikulum Tingkat Satuan Pendidikan. Jakarta: Pusat Kurikulum Badan Penelitian dan Pengembangan.

Djamarah, Saiful Bahri dan Zain, Aswan. (2010). Strategi Belajar Mengajar Edisi Revisi. Jakarta: PT. Rineka Cipta.

Gulo, W. (2002). Strategi Belajar Mengajar. Jakarta : PT. Grasindo.

Muhsetyo Gatot, dkk. (2011). Pembelajaran IPA SD. Jakarta: Universitas Terbuka

Kurikulum Tingkat Satuan Pendidikan (KTSP). 2006. Pembelajaran IPA di SD/MI. Jakarta : BNSP

Samatowa, Usman 2006 : 12. Pendidikan Dasar. WEB. 5 Oktober 2013.
Darmojo, Hendro; \& Kalligis, R.E Jenny. 1993: 6. Pendidikan Dasar. WEB. 5 Oktober 2013.

Kamus Besar Bahasa Indonesia. Pengertian Gambar. WEB. 5 Oktober 2013.

Engkoswara dkk. 1995. Alat Peraga dan Komunikasi Pendidikan. Depdikbut: Jakarta

Rochiati. 2007. Penelitian tindakan kelas. Bandung Remaja Rosdikarya.

Sadiaman, S Arif, dkk. 1996. Media Pengajaran. Jakarta : Raja Grafindo Persada.

Wibawa, Basuki. 1993. Media Pengajaran . Jakarta : Depdikbud.

Piono. 2014.1. Pedoman Penyusunan pkp-pgsd. Remaja Sera.

Wardani, IGAK dan wihardit Kuswaya.(2009). Penelitian Tindakan Kelas. Jakarta: Universitas Terbuka 